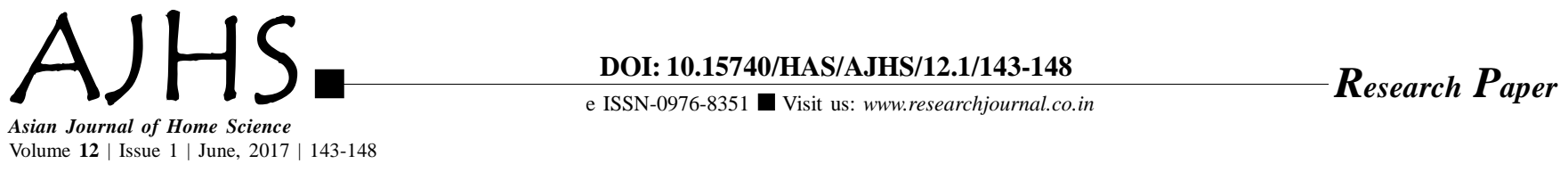

\title{
Water management strategies at household level
}

\author{
LAKHWINDER KAUR AND VINITA PANDEY
}

Received: 23.02.2017; Revised: 10.04.2017; Accepted: 27.04.2017

See end of the paper for authors' affiliations

\section{LAKHWINDER KAUR}

Department of Extension Education,

Punjab Agricultural University,

LUDHIANA (PUNJAB) INDIA
ABSTRACT : The present study entitled 'Water management strategies at household level' was conducted in Ludhiana district of Punjab. A sample of 150 women was interviewed to know the extent of use of water while performing various activities and to get their suggestions to save water for future use. The findings of the study highlighted that majority of the respondents belonged to age group of 29-39 years, belonged to general and nuclear family. Further sixty eight per cent of the respondents wasted water upto 'great extent' while washing of vegetables directly under running taps and 53.33 per cent wasted water while brushing, shaving, cleaning the hand etc. most of the respondents suggested to avoid wastage of water at home. To protect the earth's most precious resource to meet the current and future human demand, paper highlighted various water management technologies to be adopted at household level to save water resources.

KEY WORDS: Extent of use, Management strategies, household

- HOW TO CITE THIS PAPER : Kaur, Lakhwinder and Pandey, Vinita (2017). Water management strategies at household level. Asian J. Home Sci., 12 (1) : 143-148, DOI: 10.15740/HAS/AJHS/12.1/143148. 